\title{
Comparison of vermiwash and vermicompost tea properties produced from different organic beds under greenhouse conditions
}

\author{
Mehdi Zarei $^{1}$ - Vahid Alah Jahandideh Mahjen Abadi ${ }^{1} \cdot$ Ameneh Moridi $^{1}$
}

Received: 3 January 2017 / Accepted: 27 November 2017 / Published online: 4 December 2017

(c) The Author(s) 2017. This article is an open access publication

\begin{abstract}
Purpose Using different organic beds to produce vermicompost may influence on quality of vermicompost and its derived productions.

Methods A greenhouse experiment was conducted to compare the properties of vermicompost, vermiwash and vermicompost tea obtained from three types of organic beds consisted of cow manure, leaf meal and a combination of cow manure and leaf meal $(1: 1 \mathrm{w} / \mathrm{w})$.

Results Cow manure vermicompost had more desirable effect on many measured traits toward leaf meal and combination of leaf meal and cow manure vermicomposts. Vermicompost tea obtained from three vermicompost types was richer in terms of macro and micro nutrients, $\mathrm{C} / \mathrm{N}$, percent of organic matter and organic carbon toward the vermiwash produced from the same vermicompost. Vermiwash and vermicompost tea produced from cow manure vermicompost were at first order in majority of measured traits toward others.

Conclusions Generally vermicompost which was richer in nutrient concentrations affected intensively quality of vermiwash and vermicompost tea produced from it.
\end{abstract}

Keywords Vermicompost $\cdot$ Liquid organic fertilizers $\cdot$ Organic beds

\section{Introduction}

Industry of domestic animals production, especially industrial dairies have led to produce an enormous value of organic wastes so far. Cow manure and leaf meal are the most widely used as bed ingredients in greenhouse cultures in Iran. These organic wastes can be useful to apply in enhancing soil physicochemical properties and fertility (Bansal and Kapoor 2000). One of the most important

Electronic supplementary material The online version of this article (https://doi.org/10.1007/s40093-017-0186-2) contains supplementary material, which is available to authorized users.

Mehdi Zarei

mehdizarei@shirazu.ac.ir

Vahid Alah Jahandideh Mahjen Abadi

vahid.jahandideh67@gmail.com

Ameneh Moridi

ameneh.moridi@yahoo.com

1 Department of Soil Science, College of Agriculture, Shiraz University, Shiraz, Iran methods of processing organic wastes is recycling it as an organic fertilizer. Not only this process reduces sanitary and environmental problems, but also a great value of organic fertilizer is produced during it. For this, using earthworms has a specific role to produce organic fertilizer from waste named vermicompost (Suthar and Singh 2008). Vermicompost is an eco-friendly non-toxic that consumes low energy input for composting and is a recycled biological product. The major advantages of vermicompost are desirable smell, balanced $\mathrm{pH}$, low electrical conductivity, high cation exchange capacity, concentrations of available nutrients and plant growth promoting microorganisms. Vermicompost has been considered as a material containing plant growth promoting compounds including enzymes, different hormones and so many other unspecified compounds (Atiyeh et al. 2002). Orozco et al. (1996) stated that vermicompost is more sustainable than primary parent materials and its nutrients are more available. Because vermicomposting through earthworms is an eco biotechnological process that transforms energy rich and complex organic substances into a stabilized vermicompost (Benitez et al. 2000). These materials cause useful changes in plant growth bed which leads to increase 
plant growth. All useful changes occur because of mutual interaction between microorganisms and earthworms (Gallardo-Lara and Nogales 1987; Marinari et al. 2000).

Vermiwash is the liquid gathered by passing water among a path of soil containing active worms and organic bed. It is a combination of earthworm mucous discharges, nutrients, microorganisms and plant growth promoting materials (Gopal et al. 2010). Vermiwash is produced by different methods in which, it is assumed that microbial activities and nutrients are transformed from vermicompost into its extraction. This liquid partially comes from body of earthworm (as worms body contains plenty of water) and is rich in amino acids, vitamins, nutrients like nitrogen, potassium, magnesium, zinc, calcium, iron, and copper and some growth hormones like auxins and cytokines (Suthar 2010a). There are some strong evidences proving that vermiwash have impressive benefits, but these benefits are dependant on quality of used substrate producing vermiwash (Scheuerell and Mahaffee 2002). Vermiwash considers a biotic aqua fertilizer which is applied as pesticides and also contains plant essential nutrients. Vermiwash has anti-spawning effects on insects (Zhu et al. 2001). Leaf nutrition with vermiwash obtained from municipal wastes improved the photosynthesis activity, plant physiology and performance (Astaraei and Ivani 2008).

Nath et al. (2009) reported that vermiwash amended with phytohormones, enzymes and vitamins improved plant growth and yield and also increased plant resistance against different diseases. The results of Quail and Ibrahim (2013) indicated that for mung bean (Vigna radiate L.), using leached vermicompost and vermiwash, germination was higher in $10 \%$ vermiwash than in treatment with $10 \%$ vermicompost leachate.

Generally, vermicompost elutriate (vermicompost tea) is produced by placing a defined quantity of vermicompost into water and shaking it for a defined period of time. Vermicompost is the main component of vermicompost tea and the source and quality of used vermicompost is one of the main points in this regard (Scheuerell and Mahaffee 2004). It was reported that the effects of vermicompost tea and vermicompost are the same (Edris et al. 2003; Quial and Ibrahim 2013; Edwards et al. 2006). Unlike vermicompost, vermicompost tea can be applied on plant directly. Application of vermicompost tea as a foliar application causes to promote the growth of many healthy plants, increases plants sustainability against pests and diseases and accelerates degradation of toxic materials. Organic tea usage leads to increase in power and plant resistance toward bacteria and fungi diseases and this is due to existence of micro and macro-nutrients, hormones, vitamins, plant enzymes and also organic chelating factors which increase nutrients availability (Merrill and McKeon 1998). Unlike vermicompost, diluted vermicompost tea is applied sometimes in soil and sometimes in foliar spray but its worth as a nutritional treatment has not been determined yet (Gaskell et al. 2000). Many liquid fertilizers and organic tea are capable of providing essential micronutrients which can be either injected to every irrigation system or used in foliar application (Gaskell et al. 2000). Using different organic beds to produce vermicompost may influence on the quality of vermicompost and its derived productions. This research aimed to assess the effect of different beds of vermicompost on quality of vermiwash and vermicompost tea obtained from it. Considering to existed the enormous value of cow manure and leaf meal, these two resources were selected in this research and the properties of vermicompost, vermiwash and vermicompost tea produced from them were compared with standard methods together in greenhouse condition.

\section{Methods}

\section{Organic beds sources}

In this experiment, considering the enormous value of cow manure and leaf meal, these two resources were selected. Cow manure and leaf meal were provided from animal husbandry station and green space at College of Agriculture, Shiraz University, Iran, respectively. These materials were pre composted for 1 month. While preparing leaf meals, leaves are air-dried, and then ground and stored in sacks. Some chemical properties of pre composted cow manure and leaf meal were measured with standard methods and are presented in Table 1.

Table 1 Some properties of used leaf meal and cow manure

\begin{tabular}{llll}
\hline Parameters & Leaf meal & Cow manure & $\begin{array}{l}\text { Leaf } \\
\text { meal:cow } \\
\text { manure }(1: 1)\end{array}$ \\
\hline $\mathrm{pH}$ & 8.07 & 8.26 & 8.19 \\
$\mathrm{EC}(\mathrm{dS} / \mathrm{m})$ & 1.03 & 2.34 & 1.56 \\
$\mathrm{OM}(\%)$ & 42.7 & 61.8 & 52.1 \\
$\mathrm{OC}(\%)$ & 24.7 & 35.8 & 30.2 \\
$\mathrm{C} / \mathrm{N}$ & 45.9 & 35.1 & 34.7 \\
$\mathrm{Fe}(\mathrm{mg} / \mathrm{kg})$ & 334 & 956 & 678 \\
$\mathrm{Mn}(\mathrm{mg} / \mathrm{kg})$ & 52.4 & 85.4 & 67.5 \\
$\mathrm{Cu}(\mathrm{mg} / \mathrm{kg})$ & 2.16 & 5.60 & 3.15 \\
$\mathrm{Zn}(\mathrm{mg} / \mathrm{kg})$ & 25.3 & 65.6 & 41.4 \\
$\mathrm{~N}(\%)$ & 0.54 & 1.02 & 0.87 \\
$\mathrm{P}(\mathrm{mg} / \mathrm{kg})$ & 879 & 1243 & 1056 \\
$\mathrm{~K}(\mathrm{mg} / \mathrm{kg})$ & 998 & 2567 & 1456 \\
\hline
\end{tabular}




\section{Production of vermicompost, vermiwash and vermicompost tea}

The experiment was conducted in a greenhouse with day/ night temperature of $24 \pm 3{ }^{\circ} \mathrm{C} / 15 \pm 3{ }^{\circ} \mathrm{C}, 60-70 \%$ average relative humidity $(\mathrm{RH})$ and a photoperiod of $16(\mathrm{~h})$ with photosynthetic photon flux (PPF) of $800 \mu \mathrm{mol} / \mathrm{m}^{2} / \mathrm{s}$.

To produce organic fertilizers, plastic containers were selected. A hole at the base of the each container drilled to fix a valve to it. A base layer of gravel to a height of $5 \mathrm{~cm}$ and above it a $2 \mathrm{~cm}$ layer of coarse sand were put. On the coarse sand layer, $1000 \mathrm{~g}$ pre-decomposed each organic bed was placed and moistened the different layer using water. Combinational bed was prepared with mixing leaf meal and cow manure at the ratio of 1:1 by weight. Thirty numbers of live weight of clitellated and young non-clitellated of Eisenia foetida earthworms (approximately $17 \mathrm{~g}$ live weight) were introduced into each bed. Earthworms were provided from vermicompost field in College of Agriculture, Shiraz University, Iran. There was a wicker cover creating shadow on the bed of earthworms' activity. During the whole process, moisture content was maintained at $75 \pm 5 \%$ by pouring non-chlorinated tap water into each bed. Excessive latexes were exited via improvised valve below the container. After 45 days, vermiwash was collected in a period of 15 days by valve embedded under the barrel. The experiment allowed acting for 80 days, which the bed material converted into vermicompost and at end the vermicompost were collected.

Diver (1998) reported that there are two main methods producing vermicompost tea: the method of fermentation (without aeration) and the method along with aeration. Through present experiment, vermicompost tea was produced by the method along with aeration. The ratio between water and vermicompost is important. With too much water, nutrients concentration reduces in whole solution and with too much compost, a large amount of nutrients available to the microorganisms and due to lack of oxygen, anaerobic conditions arise. Many studies have used the method of Weltzien (1991) with ratios of 1:3-1:10. Considering the mentioned matters, vermicompost tea was produced providing a 1:10 volumetric ratio of each vermicompost type and distilled water under aeration conditions provided by aquarium pomp. Samples were kept for $24 \mathrm{~h}$ at the temperature of $25{ }^{\circ} \mathrm{C}$ and then filtering process was performed by use of a jaconet cloth (Brinton and Droffner 1995).

\section{Chemical and biological analysis}

Numbers of earthworms in vermicompost obtained from three different organic beds were separated by light separation and hand sorting method through whole bed and then weighed. The cocoons were sorted manually.
To determine the properties of organic beds, vermicompost and vermicompost extracts were used from standard methods. Liquid organic fertilizers were poured into a crucible and placed in an oven (Gallenkamp Model OV-440, England) at $70^{\circ} \mathrm{C}$. After that, the condensed materials were ashed in a heavy-duty muffle furnace (Thermolyne Thermo Scientific FA1740-1, USA) at $350{ }^{\circ} \mathrm{C}$ (EPA 2004). Total nitrogen by the method of Micro-Kjeldahl (Bremner and Mulvaney 1982), total potassium using flame photometer (Page et al. 1982) and total phosphorous by molybdate vanadate yellow method (Chapman and Pratt 1961) were estimated. Concentrations of $\mathrm{Fe}, \mathrm{Zn}, \mathrm{Cu}$ and $\mathrm{Mn}$ by the method of dry ashing and digesting in $\mathrm{HCl} 2 \mathrm{M}$, and finally were determined via using atomic absorption spectrometry model AA-670G method (Chapman and Pratt 1961). Organic matter was estimated by the method of oxidation with chromic acid then titration with ferrous ammonium sulfate (Nelson and Sommers 1982). A 1:5 ratio of water to vermicompost suspension was used to determine $\mathrm{pH}$ (Thomas 1996) and electrical conductivity (Rhoades 1996) of vermicompost, however, for vermiwash and vermicompost tea the mentioned parameters were determined without diluting.

\section{Statistical analysis}

Comparison of vermicomposts obtained from three different organic beds was conducted in a completely randomized design with three organic beds (leaf meal, cow manure and a combination of cow manure and leaf meal $(1: 1 \mathrm{w} / \mathrm{w}))$ and three replications. Comparison of vermiwash and vermicompost tea obtained from types of vermicompost was conducted with a factorial arrangement in a completely randomized design with three replications and three factors: two levels of leaf meal vermicompost (vermiwash and vermicompost tea of leaf meal vermicompost), two levels of cow manure vermicompost (vermiwash and vermicompost tea of cow manure vermicompost) and two levels of combination of cow manure and leaf meal vermicompost (vermiwash and vermicompost tea of combination of cow manure and leaf meal vermicompost). Data analysis was performed by use of SAS 9.1 statistical program ANOVA. Means were compared by Duncan's Multiple Range Test (DMRT) using SAS statistical software.

\section{Results and discussion}

\section{Worm growth and reproduction}

The results indicated that maximum worms number $(87.6$ No./per bed) was recorded in the vermicompost produced from cow manure bed and the minimum (52.6 No./per bed) was observed in vermicompost produced from leaf 
meal. Also maximum (44.3 g/per bed) and minimum (26.4 $\mathrm{g} /$ per bed) weight of worms were related to the treatments of cow manure and leaf meal, respectively, which had a significant difference with other treatments. There was no significant difference between cocoons number in different beds (Table 2).

The results of this research are in accordance with the results of Warman and Anglopez (2010) who investigated the effect of different types of feedstocks including kitchen paper waste, kitchen yard waste, cattle manure yard waste on the worm weight and concluded that worm weight in this feedstock was different and related to type of feedstock and durations of vermicomposting. Studies showed that the kind, palatability and quality of food (in term of their chemistry) directly affected the survival growth rate and reproduction potential of earthworms (Suthar 2010b; Deka et al. 2011). In this study, the drastic variation in worm number and weight in vermicompost types were probably related to palatability as well as chemical nature of the feeding stuff. It may be due to increased feed for earthworm which was evident from higher nutrient content in cow manure (Table 4).

\section{Chemical properties of vermicomposts obtained from organic beds}

Based on results the highest EC $(3.44 \mathrm{dS} / \mathrm{m})$ was in the vermicompost produced from cow manure and the lowest $(1.53 \mathrm{dS} / \mathrm{m})$ was in vermicompost produced from leaf meal (Table 3). A reason of high salinity in produced vermicomposts in comparison with primary bed (Table 1) can be because of decomposing bed during the worm processes of digest and excretion of worm which increased the concentration of available ions toward the primary bed (John Paul et al. 2011). This result is well supported by the results of the previous works with different earthworm species during vermicomposting (Karmegam and Daniel 2009; Raja Sekar and Karmegam 2009; Prakash and Karmegam 2010).

According to the results, the highest and lowest quantity of $\mathrm{pH}$ which were 7.26 and 7.06 in the vermicompost produced from leaf meal and cow manure, respectively (Table 3). It was observed that $\mathrm{pH}$ was reduced during the process of vermicomposting that is accordance with the results of John Paul et al. (2011). This reduction in $\mathrm{pH}$ value can be due to high concentration of $\mathrm{CO}_{2}$ and organic acids produced by microorganisms and earthworm. Biotic converting of organic matter to different intermediate materials,
Table 2 Comparison of worm number and weight and cocoon number of vermicompost types obtained from organic beds

\begin{tabular}{llll}
\hline Types of vermicompost & $\begin{array}{l}\text { Worms number (no./ } \\
\text { per bed) }\end{array}$ & $\begin{array}{l}\text { Worms weight (g/ } \\
\text { per bed) }\end{array}$ & $\begin{array}{l}\text { Cocoons } \\
\text { number (no./ } \\
\text { per bed) }\end{array}$ \\
\hline Leaf meal vermicompost & $52.6 \mathrm{c}$ & $26.4 \mathrm{c}$ & $12.3 \mathrm{a}$ \\
Cow manure vermicompost & $87.6 \mathrm{a}$ & $44.3 \mathrm{a}$ & $20.0 \mathrm{a}$ \\
Leaf meal:cow manure vermicompost & $70.6 \mathrm{~b}$ & $35.8 \mathrm{~b}$ & $18.3 \mathrm{a}$ \\
\hline
\end{tabular}

For each parameter, values in columns followed by the different small letters are significantly different at 0.05 levels. The data shown are the means of three replicates

\begin{tabular}{llllll}
\hline Types of vermicompost & OM $(\%)$ & OC $(\%)$ & $\mathrm{pH}$ & $\mathrm{EC}(\mathrm{dS} / \mathrm{m})$ & $\mathrm{C} / \mathrm{N}$ \\
\hline Leaf meal vermicompost & $35.6 \mathrm{c}$ & $20.6 \mathrm{c}$ & $7.26 \mathrm{c}$ & $1.53 \mathrm{c}$ & $13.0 \mathrm{~b}$ \\
Cow manure vermicompost & $59.9 \mathrm{a}$ & $34.7 \mathrm{a}$ & $7.06 \mathrm{a}$ & $3.44 \mathrm{a}$ & $12.5 \mathrm{c}$ \\
Leaf meal:cow manure vermicompost & $50.9 \mathrm{~b}$ & $29.5 \mathrm{~b}$ & $7.11 \mathrm{~b}$ & $1.98 \mathrm{~b}$ & $14.6 \mathrm{a}$ \\
\hline
\end{tabular}

For each parameter, values in columns followed by the different small letters are significantly different at

0.05 levels. The data shown are the means of three replicates
Table 3 Comparison of OM, $\mathrm{OC}, \mathrm{pH}, \mathrm{EC}$ and $\mathrm{C} / \mathrm{N}$ of vermicompost types obtained from organic beds

Table 4 Comparison of nutrients concentration of vermicompost types obtained from organic beds

\begin{tabular}{llllllll}
\hline Types of vermicompost & $\mathrm{N}(\%)$ & $\mathrm{P}(\mathrm{mg} / \mathrm{kg})$ & $\mathrm{K}(\mathrm{mg} / \mathrm{kg})$ & $\mathrm{Fe}(\mathrm{mg} / \mathrm{kg})$ & $\mathrm{Cu}(\mathrm{mg} / \mathrm{kg})$ & $\mathrm{Zn}(\mathrm{mg} / \mathrm{kg})$ & $\mathrm{Mn}(\mathrm{mg} / \mathrm{kg})$ \\
\hline Leaf meal vermicompost & $1.58 \mathrm{c}$ & $1775 \mathrm{c}$ & $1769 \mathrm{c}$ & $515 \mathrm{c}$ & $4.15 \mathrm{c}$ & $45.8 \mathrm{c}$ & $99 \mathrm{c}$ \\
Cow manure vermicompost & $2.78 \mathrm{a}$ & $2796 \mathrm{a}$ & $3195 \mathrm{a}$ & $1286 \mathrm{a}$ & $9.46 \mathrm{a}$ & $85.6 \mathrm{a}$ & $145 \mathrm{a}$ \\
Leaf meal:cow manure vermicompost & $2.2 \mathrm{~b}$ & $2552 \mathrm{~b}$ & $2789 \mathrm{~b}$ & $1097 \mathrm{a}$ & $7.08 \mathrm{~b}$ & $69.4 \mathrm{~b}$ & $126 \mathrm{~b}$ \\
\hline
\end{tabular}

For each parameter, values in columns followed by the different small letters are significantly different at 0.05 levels. The data shown are the means of three replicates 
intensive mineralization of organic nitrogen to nitrate and nitrite and phosphorous to ortho-phosphates can be considered as other reasons of $\mathrm{pH}$ reduction (Gunadi et al. 2002). Considering to what were mentioned, $\mathrm{pH}$ reduction in the bed of cow manure was more than other beds because cow manure was richer than other beds (Table 1) and worms activity and number were more in this treatment (Table 2).

Loh et al. (2005) investigated the effect of two beds of cattle and goat manure on $\mathrm{pH}$ changes in the vermicompost produced from them, they resulted that $\mathrm{pH}$ changed from neutral and alkaline values in beds to acidic values in the provided vermicompost. The same results obtained by Garg and Kaushik (2005). Hartenstein (1981) stated that pH reduction is an important factor for maintenance of nitrogen, because this important nutrient volatilize in the form of ammoniac gas at alkaline $\mathrm{pH}$.

The results showed that, the highest values of organic matter and carbon were related to the vermicompost produced from cow manure which were 59.9 and $34.7 \%$, respectively, and also the lowest values of them were measured in vermicompost produced from leaf meal which were 35.6 and $20.6 \%$, respectively (Table 3 ). Also, the highest value of $\mathrm{C} / \mathrm{N}$ ratio (14.6) was observed in vermicompost produced from combinational bed of cow manure and leaf meal and the lowest value of this ratio (12.5) was in the vermicompost produced from cow manure (Table 3). Richard (1976) reported that combination of manure with leaf meal leads to increase in $\mathrm{C} / \mathrm{N}$ ratio.

All vermicomposts also showed reduction of $\mathrm{C} / \mathrm{N}$ ratio than in the primary beds (Tables 1, 3). Because of the combined action of microorganisms and the earthworms, a large fraction of the organic matter in the primary beds is lost as $\mathrm{CO}_{2}$ by the end of the vermicomposting period (Jayakumar et al. 2011). Govindan (1998) showed that the production of mucus and nitrogenous excrements enhanced the level of nitrogen in the vermicompost and it brought down the ratio of carbon to nitrogen which is most essential in the humification process. Also, the reduction of $\mathrm{C} / \mathrm{N}$ ratio during vermicomposting is achieved by the combustion of carbon substrates during respiration.

\section{Nutrients concentration of vermicomposts obtained from organic beds}

Results indicated that vermicompost produced from cow manure significantly had more concentrations of $\mathrm{Mn}, \mathrm{Zn}$, $\mathrm{Cu}, \mathrm{Fe}, \mathrm{K}, \mathrm{P}$ and $\mathrm{N}$ than two another beds (Table 4). The nutrient level of vermicompost depends on the nature of the organic material used as food source for earthworms (Garg et al. 2006; Suthar and Singh 2008). The higher percentage of nutrients level in vermicompost produced from cow manure in comparison with leaf meal may be attributed to the higher mineralization caused by earthworm action along with microorganisms and quality of primary beds (cow manure bed was richer than leaf meal bed). Amount of available nutrients increased through the vermicompost production process (Tables 1, 4). One reason for this result is the presence of carbon in the vermicompost for worms and microorganisms activity (Jayakumar et al. 2011). Losses in organic carbon might be responsible for $\mathrm{N}$ upgrading (Sangwan et al. 2008; Karmegam and Daniel 2009).

Increasing the level of $\mathrm{P}$ content during vermicomposting is may be due to mineralization of $\mathrm{P}$ due to phosphatases activity of microorganisms and earthworms (Krishnamoorthy 1990). The increased level of $\mathrm{Zn}$ and $\mathrm{Fe}$ in vermicompost indicated accelerated mineralization with selective feeding by earthworms on materials containing these elements. The increased level of nutrients in the vermicomposts was in accordance with the results of earlier works (Suthar 2007; Jayakumar et al. 2011).

\section{Chemical properties of liquid organic fertilizers obtained from different vermicomposts}

The results indicated that the highest values of $\mathrm{OC}$ and $\mathrm{OM}$ (12.22 and $21.06 \%$, respectively) were in the vermicompost tea produced of cow manure vermicompost and the lowest values of them ( 0.60 and $1.04 \%$, respectively) were measured in the vermiwash produced from leaf meal vermicompost. In each vermicompost type, vermicompost tea had significantly higher OC and OM than vermiwash. Also the highest value of $\mathrm{pH}$ was measured in the vermiwash produced from leaf meal vermicompost and the lowest value was observed through the vermicompost tea produced from cow manure. The highest (6.54) and lowest (1.35) amounts of the $\mathrm{C} / \mathrm{N}$ ratio were observed through the vermicompost tea and vermiwash produced from leaf meal vermicompost, respectively. In general, in each vermicompost type the amount of $\mathrm{C} / \mathrm{N}$ in vermicompost tea was significantly more than vermiwash (Table 5). At each vermicompost type, the value of $\mathrm{pH}$ in the produced vermiwash was significantly more than vermicompost tea. The highest value of EC $(2.76 \mathrm{dS} / \mathrm{m})$ was related to the vermicompost tea produced from cow manure vermicompost and the lowest value $(1.52 \mathrm{dS} / \mathrm{m})$ was observed in the vermiwash produced from leaf meal vermicompost. Greater concentrations of $\mathrm{P}, \mathrm{N}, \mathrm{K}$, $\mathrm{Mg}, \mathrm{Na}, \mathrm{Zn}$ and $\mathrm{Cu}$ in vermicompost tea produced from vermicompost types, especially produced from cow manure vermicompost ("Nutrients concentration of liquid organic fertilizers obtained from different vermicomposts" section, Table 6) resulted in greater EC. The same results obtained by Pant et al. (2012). It was notable that the nature of the process vermicompost tea was found to have more effect on the chemical properties, as shown by significant differences between the characteristics of the two types of vermicomposted materials (leaf meal and cow manure). It is thought 
Table 5 Comparison of OM, $\mathrm{OC}, \mathrm{pH}, \mathrm{EC}$ and $\mathrm{C} / \mathrm{N}$ of liquid organic fertilizers (LOFs) obtained from vermicompost types

\begin{tabular}{lllllll}
\hline Types of vermicompost & LOFs & OM\% & OC\% & pH & EC $(\mathrm{dS} / \mathrm{m})$ & $\mathrm{C} / \mathrm{N}$ \\
\hline Leaf meal vermicompost & Vermicompost tea & $14.85 \mathrm{c}$ & $8.62 \mathrm{c}$ & $7.24 \mathrm{~b}$ & $1.80 \mathrm{~cd}$ & $6.54 \mathrm{a}$ \\
& Vermiwash & $1.04 \mathrm{f}$ & $0.60 \mathrm{e}$ & $7.56 \mathrm{a}$ & $1.52 \mathrm{~d}$ & $1.35 \mathrm{~d}$ \\
Cow manure vermicompost & Vermicompost tea & $21.06 \mathrm{a}$ & $12.22 \mathrm{a}$ & $7.06 \mathrm{c}$ & $2.76 \mathrm{a}$ & $5.35 \mathrm{~b}$ \\
& Vermiwash & $3.38 \mathrm{~d}$ & $1.96 \mathrm{~d}$ & $7.52 \mathrm{a}$ & $2.24 \mathrm{~b}$ & $2.37 \mathrm{c}$ \\
Leaf meal:cow manure vermicompost & Vermicompost tea & $17.94 \mathrm{~b}$ & $10.41 \mathrm{~b}$ & $7.19 \mathrm{bc}$ & $2.70 \mathrm{a}$ & $6.14 \mathrm{ab}$ \\
& Vermiwash & $2.05 \mathrm{e}$ & $1.19 \mathrm{de}$ & $7.54 \mathrm{a}$ & $2.12 \mathrm{bc}$ & $2.34 \mathrm{c}$ \\
\hline
\end{tabular}

For each parameter, values in columns followed by the different small letters are significantly different at 0.05 levels. The data shown are the means of three replicates

Table 6 Comparison of nutrients concentration of liquid organic fertilizers (LOFs) obtained from vermicompost types

\begin{tabular}{|c|c|c|c|c|c|c|c|c|}
\hline Types of vermicompost & LOFs & $\mathrm{N}(\%)$ & $\mathrm{P}(\mathrm{mg} / \mathrm{l})$ & $\mathrm{K}(\mathrm{mg} / \mathrm{l})$ & $\mathrm{Fe}(\mathrm{mg} / \mathrm{l})$ & $\mathrm{Cu}(\mathrm{mg} / \mathrm{l})$ & $\mathrm{Zn}(\mathrm{mg} / \mathrm{l})$ & Mn (mg/l) \\
\hline \multirow[t]{2}{*}{ Leaf meal vermicompost } & Vermicompost tea & $1.32 \mathrm{~b}$ & $1118 \mathrm{c}$ & $1703 \mathrm{~cd}$ & $7.57 \mathrm{~b}$ & $0.04 b$ & $13.30 \mathrm{c}$ & $0.48 b$ \\
\hline & Vermiwash & $0.45 \mathrm{c}$ & $311 d$ & $820 \mathrm{e}$ & $1.27 \mathrm{c}$ & Not detected & $7.96 \mathrm{c}$ & Not detected \\
\hline \multirow[t]{2}{*}{ Cow manure vermicompost } & Vermicompost tea & $2.31 \mathrm{a}$ & $1862 \mathrm{a}$ & $2482.3 \mathrm{a}$ & $12.07 \mathrm{a}$ & $0.09 \mathrm{a}$ & $25.56 \mathrm{a}$ & $0.47 b$ \\
\hline & Vermiwash & $0.83 \mathrm{c}$ & $1677 \mathrm{a}$ & $1907.3 \mathrm{bc}$ & $3.09 \mathrm{c}$ & Not detected & 8.76de & Not detected \\
\hline \multirow{2}{*}{$\begin{array}{l}\text { Leaf meal:cow manure vermicom- } \\
\text { post }\end{array}$} & Vermicompost tea & $1.71 \mathrm{~b}$ & $1377 b$ & $2104 b$ & $10.43 \mathrm{ab}$ & $0.08 \mathrm{a}$ & $19.93 b$ & $0.51 \mathrm{a}$ \\
\hline & Vermiwash & $0.51 \mathrm{c}$ & $1004 c$ & $1655 \mathrm{~d}$ & $3.02 \mathrm{c}$ & Not detected & $10.56 \mathrm{~d}$ & Not detected \\
\hline
\end{tabular}

For each parameter, values in columns followed by the different small letters are significantly different at 0.05 levels. The data shown are the means of three replicates

that the superior biochemical and physical properties of vermicompost over thermophilic compost are reflected in tea quality (Edwards et al. 2006). These results are in accordance with the results of Pant et al. (2012) that reported either vermicompost or thermophilic compost can be used for the production of compost tea or vermicompost tea but the tea quality predicted based on compost or vermicompost quality. Carballo et al. (2009) stated that whole produced vermicompost tea cannot have the same quality and content.

\section{Nutrients concentration of liquid organic fertilizers obtained from different vermicomposts}

The results indicated that the total concentration maximum of N, P, K (2.31\%, 1862.32 and $2482.3 \mathrm{mg} / \mathrm{l}$, respectively) were in the vermicompost tea produced from cow manure vermicompost and the lowest values of these nutrients were measured in the vermiwash produced from leaf meal vermicompost $(0.45 \%, 311$ and $820 \mathrm{mg} / \mathrm{l}$, respectively). There was no significant difference between $\mathrm{N}$ percent in the vermiwash produced from three types of vermicompost. $\mathrm{P}$ concentration in vermicompost tea produced from leaf meal vermicompost and combination of cow manure and leaf meal vermicompost was significantly more than their vermiwash, while there was no significant difference between $\mathrm{P}$ concentration in the vermicompost tea and vermiwash produced from cow manure vermicompost. $\mathrm{K}$ concentration in the vermicompost tea produced from three types of vermicompost was significantly more than vermiwash produced from them. The highest values of $\mathrm{Cu}, \mathrm{Zn}$ and $\mathrm{Fe}(0.09,25.56$ and $12.07 \mathrm{mg} / \mathrm{l}$, respectively) were in vermicompost tea produced from cow manure vermicompost, but the lowest values of Fe and $\mathrm{Zn} \mathrm{(1.27}$ and $7.96 \mathrm{mg} / \mathrm{l}$, respectively) were in the vermiwash produced from leaf meal vermicompost. The maximum of Mn concentration was $0.51 \mathrm{mg} / \mathrm{l}$ which was observed in vermicompost tea produced from combination of cow manure and leaf meal vermicompost (Table 6). Results showed that vermicompost which was richer in nutrient concentrations (Table 4) affected intensively the quality of vermiwash and vermicompost tea produced from it. Pant et al. (2012) reported that higher mineral concentrations in compost explain greater concentrations of those nutrients in its tea. Positive correlations between mineral nutrient concentrations of compost and compost tea also explain the greater concentration of those nutrients in chicken manure-based thermophilic compost tea compared to the other teas.

We suspect that the design of the vermiwash beds may have remaining nutrients directly into the bedding material compared with vermicompost tea. Hargreaves et al. (2008) stated that vermicompost tea is more effective for enhancing plant growth conditions because of being richer in plant required macro and micro nutrients. Also N, P, K and many of micronutrients are considered as the main nutrients of vermiwash (Shivsubramanian and Ganeshkumar 2004). 
Almost, the behaviors of the nutrients especially $\mathrm{N}$ for different vermicomposts and their tea products were similar. It may be due to the method used for vermicompost tea preparation and analysis (See the method section). The drying process may increase the concentrations of different nutrients due to condensation. Also, during the tea preparation, microbial population and activities, especially nitrogenfixing microorganisms and $\mathrm{N}$ containing compounds may be increased. The decline in organic carbon (Tables 3, 5) might be responsible for $\mathrm{N}$ upgrading that was similar to the results of other researchers (Sangwan et al. 2008; Karmegam and Daniel 2009).

\section{Conclusion}

Vermicompost obtained from cow manure had more desirable effect on many measured traits toward leaf meal and combinational leaf meal and cow manure vermicomposts. Also vermicompost tea produced from all three vermicompost types was richer in terms of macro and micro nutrients, $\mathrm{OM} \%, \mathrm{OC} \%$ and $\mathrm{C} / \mathrm{N}$ toward the vermiwash produced from the same vermicompost. Vermiwash and vermicompost tea produced from cow manure vermicompost were at first order in majority of measured traits in comparison with others. Generally, the results showed that, qualities of vermiwash and vermicompost tea depend on type of beds and their vermicompost used.

Acknowledgment The authors wish to thank Shiraz University for providing research facilities.

Open Access This article is distributed under the terms of the Creative Commons Attribution 4.0 International License (http://creativecommons.org/licenses/by/4.0/), which permits unrestricted use, distribution, and reproduction in any medium, provided you give appropriate credit to the original author(s) and the source, provide a link to the Creative Commons license, and indicate if changes were made.

\section{References}

Astaraei AR, Ivani R (2008) Effect of organic sources as foliar spray and root media on cowpea plant. American-Eurasian J Agric Environ Sci 3:352-356

Atiyeh RM, Arancon NQ, Edwards CA (2002) The influence of earthworm-processed pig manure on the growth and productivity of marigolds. Bioresour Technol 81:103-108. https://doi. org/10.1016/S0960-8524(01)00122-5

Bansal S, Kapoor KK (2000) Vermicomposting of crop residues and cattle dung with Eisenia fetida. Bioresour Technol 73:95-98. https://doi.org/10.1016/S0960-8524(99)00173-X

Benitez E, Nogales R, Masciandro G, Ceccanthi B (2000) Isolation by isoelectric focusing of humic urease complex from earthworm Eisenia foetida processed sewedge sludge. Biol Fertil Soils 31:489-493. https://doi.org/10.1007/s003740000197
Bremner JM, Mulvaney RG (1982) Nitrogen total. In: Page AL, Miller RH, Keeney DR (eds) Methods of soil analysis. American Society of Agronomy, Madison, pp 575-624

Brinton WF, Droffner M (1995) The control of plant pathogenic fungi by use of compost teas. Biodynamics 197:12-15

Carballo T, Gil MV, Calvo LF, Moran A (2009) The influence of aeration system, temperature and compost origin on the phytotoxicity of compost tea. Compos Sci Util 17:127-139. https://doi.org/10. 1080/1065657X.2009.10702411

Chapman HD, Pratt DF (1961) Methods of analysis for soils, plants and water. University of California Press, Riverside

Deka H, Deka S, Baruah CK, Das J, Hoque S, Sarma H, Sarma NS (2011) Vermicomposting potentiality of Perionyx excavatus for recycling of waste biomass of java citronella-an aromatic oil yielding plant. Bioresour Technol 102:11212-11217. https://doi. org/10.1016/j.biortech.2011.09.102

Diver S (1998) Compost teas for plant disease control. National Center for Appropriate Technology, U.S. Department of Agriculture, ATTRA Publication

Edris AE, Shalaby A, Fadel HM (2003) Effect of organic agriculture practices on the volatile aroma components of some essential oil plants growing in Egypt. II: sweet Marjoram (Origanum marijorana L.) essential oil. Flavour Fragr J 18:345-351. https://doi. org/10.1002/ffj.1235

Edwards CA, Arancon NQ, Greytak S (2006) Effects of vermicompost teas on plant growth and disease. BioCycle 47:28-31

Gallardo-Lara F, Nogales R (1987) Effect of the application of town refuse compost on the soil-plant system: a review. Biol Wastes 19:35-62. https://doi.org/10.1016/0269-7483(87)90035-8

Garg VK, Kaushik P (2005) Vermistabilization of textile mill sludge spiked with poultry droppings by an epigeic earthworm Eisenia foetida. Bioresour Technol 96:1063-1071. https://doi. org/10.1016/j.biortech.2004.09.003

Garg P, Gupta A, Satya S (2006) Vermicomposting of different types of waste using Eisenia foetida: a comparative study. Bioresour Technol 97:391-395. https://doi.org/10.1016/j.biortech.2005.03.009

Gaskell M, Fouche B, Koike S, Lanini T, Mitchell J, Smith R (2000) Organic vegetable production in California - science and practice. Hort Technol 10:699-713

Gopal M, Gupta A, Palaniswami C, Dhanapal R, Thomas GV (2010) Coconut leaf vermiwash: a bio-liquid from coconut leaf vermicompost for improving the crop production capacities of soil. Curr Sci India 98:1202-1210

Govindan VS (1998) Vermiculture and vermicomposting. In: Trivedy RK, Arvind K (eds) Ecotechnology for pollution control and environmental management. Einviro Media, Karad, India, pp 49-57

Gunadi B, Blount C, Edward CA (2002) The growth and fecundity of Eisenia fetida (Savigny) in cattle solids pre-composted for different periods. Pedobiologia 46:15-23. https://doi. org/10.1078/0031-4056-00109

Hargreaves J, Adl MS, Warman PR, Rupasinghe HPV (2008) The effects of organic amendments on mineral element uptake and fruit quality of raspberries. Plant Soil 308:213-226. https://doi. org/10.1007/s11104-008-9621-5

Hartenstein R (1981) Production of earthworms as a potentially economic source of protein. Biotechnol Bioeng 23:1797-1811

Jayakumar M, Sivakami T, Ambika D, Karmegam N (2011) Effect of turkey litter (Meleagris gallopavo L.) vermicompost on growth and yield characteristics of paddy, Oryza sativa (ADT-37). Afr J Biotechnol 10:15295-15304. https://doi.org/10.5897/AJB11.2253

John Paul JA, Karmegam N, Daniel T (2011) Municipal solid waste (MSW) vermicomposting with an epigeic earthworm, Perionyx ceylanensis Mich. Bioresour Technol 102:6769-6773. https://doi. org/10.1016/j.biortech.2011.03.089

Karmegam N, Daniel T (2009) Investigating efficiency of Lampito mauritii (Kinberg) and Perionyx ceylanensis Michaelsen for 
vermicomposting of different types of organic substrates. Environmentalist 29:287-300. https://doi.org/10.1007/s10669-008-9195-z

Krishnamoorthy RV (1990) Mineralization of phosphorus by faecal phosphatases of some earthworms of Indian tropics. Proc Indian Acad Sci 99:509-518. https://doi.org/10.1007/BF03186414

Loh TC, Lee YC, Liang JB, Tan D (2005) Vermicomposting of cattle and goat manures by Eisenia fetida and their growth and reproduction performance. Bioresour Technol 96:111-114. https://doi. org/10.1016/j.biortech.2003.03.001

Marinari S, Masciandaro G, Ceccanti B, Grego S (2000) Influence of organic and material fertilizers on soil biological and physical properties. Bioresour Technol 72:9-17. https://doi.org/10.1016/ S0960-8524(99)00094-2

Merrill R, McKeon J (1998) Organic teas from compost and manuras. Organic Farming Research Foundation Project Report, pp 40-97

Nath G, Singh K, Singh DK (2009) Chemical analysis of vermicomposts/vermiwash of different combinations of animal, agro and kitchen wastes. Aust J Basic Appl Sci 3:3671-3676

Nelson DW, Sommers LE (1982) Total carbon and organic carbon. In: Page AL, Miller RH, Keeney DR (eds) Methods of soil analysis. American Society Agronomy, Madison

Orozco FH, Cegarra J, Trujillo LM, Roig A (1996) Vermicomposting of coffee pulp using the earthworm Eisenia fetida: effects on C and $\mathrm{N}$ contents and the availability of nutrients. Biol Fertil Soils 22:162-166. https://doi.org/10.1007/BF00384449

Page AL, Miller RH, Keeney DR (1982) Methods of soil analysis. Part 2. Chemical and microbiological properties, agronomy series, vol 9, 2nd ed. Madison, WI, American Society of Agronomy, Soil Science Society of America

Pant AP, Radovich TJK, Hue NV, Paull RE (2012) Biochemical properties of compost tea associated with compost quality and effects on pak choi growth. Sci Hortic 148:138-146. https://doi. org/10.1016/j.scienta.2012.09.019

Prakash M, Karmegam N (2010) Vermistabilization of pressmud using Perionyx ceylanensis Mich. Bioresour Technol 101:8464-8468. https://doi.org/10.1016/j.biortech.2010.06.002

Quial S, Ibrahim MH (2013) A review on potential of vermicomposting derived liquids in agricultural use. Int J Sci Res Publ 3:1-6

Raja Sekar K, Karmegam N (2009) Efficiency of the earthworm, Eisenia fetida (Sav.) in vermistabilization of silkworm litter mixed with leaf litter. Int J Appl Environ Sci 4:481-486

Rhoades JD (1996) Salinity: electrical conductivity and total dissolved solids. In: Sparks DL (ed) Methods of soil analysis, Part 3, chemical methods. SSSA, Madison, pp 417-435

Richard T (1976) Health and safety precautions. Cornell Cooperative Extension, Operator's Fact, pp 1-10

Sangwan P, Kaushik CP, Garg VK (2008) Feasibility of utilization of horse dung spiked filter cake in vermicomposters using exotic earthworm Eisenia fetida. Bioresour Technol 99:2442-2448. https://doi.org/10.1016/j.biortech.2007.04.061
Scheuerell S, Mahaffee W (2002) Compost tea: principles and prospects for plant disease control. Compos Sci Util 10:313-338. https://doi.org/10.1080/1065657X.2002.10702095

Scheuerell SJ, Mahaffee WF (2004) Compost tea as a container medium drench for suppressing seedling damping-off caused by Pythium ultimum. Phytopathol 94:1156-1163. https://doi. org/10.1094/PHYTO.2004.94.11.1156

Shivsubramanian K, Ganeshkumar M (2004) Influence of vermiwash on the biological productivity of Marigold. Madras Agric J 91:221-225

Suthar S (2007) Vermicomposting potential of Perionyx sansibaricus (Perrier) in different waste materials. Bioresour Technol 97:24742477. https://doi.org/10.1016/j.biortech.2006.05.008

Suthar S (2010a) Evidence of plant hormone like substances in vermiwash: an ecologically safe option of synthetic chemicals for sustainable farming. Ecol Eng 36:1089-1092. https://doi. org/10.1016/j.ecoleng.2010.04.027

Suthar S (2010b) Pilot-scale vermireactors for sewage sludge stabilization and metal remediation process: comparison with small-scale vermireactors. Ecol Eng 36:703-712. https://doi.org/10.1016/j. ecoleng.2009.12.016

Suthar S, Singh S (2008) Vermicomposting of domestic waste by using two epigeic earthworms (Perionyx excavatus and Perionyx sansibaricus). Int J Environ Sci Technol 5:99-106. https://doi. org/10.1007/BF03326002

Thomas GW (1996) Soil PH and soil acidity. In: Sparks DL (ed) Methods of soil analysis, Part 3 chemical methods. SSSA, Madison, pp 475-490

U.S. Environmental Protection Agency (2004) Multi-agency radiological laboratory analytical protocols manual (MARLAP). USEPA 402-B-04-00IA

Warman PR, Anglopez MJ (2010) Vermicompost derived from different feeds tocks as a plant growth medium. Bioresour Technol 101:4479-4483. https://doi.org/10.1016/j.biortech.2010.01.098

Weltzien HC (1991) Biocontrol of foliar fungal diseases with compost extracts. In: Andrews JM, Hirano SS (eds) Microbial ecology of leaves. Springer, New York, pp 430-450

Zhu BCR, Henderson G, Chen F, Fei H, Laine RA (2001) Evaluation of vetiver oil and seven insect-active essential oils against Formosan subterranean termite. J Chem Ecol 27:1617-1625. https://doi.org /10.1023/A:1010410325174

Publisher's Note Springer Nature remains neutral with regard to jurisdictional claims in published maps and institutional affiliations. 